\title{
Influence of exonic polymorphisms in the gene for LDL receptor- related protein (LRP) on risk of coronary artery disease
}

\author{
Anothai Pocathikorn ${ }^{\mathrm{a}, \mathrm{c}, \mathrm{d}}$, Britt Granath ${ }^{\mathrm{d}}$, Els Thiry ${ }^{\mathrm{e}}$, Fred Van Leuven ${ }^{\mathrm{e}}$, \\ Roger Taylor ${ }^{\mathrm{b}, \mathrm{d}}$, Cyril Mamotte ${ }^{\mathrm{a}, *}$ \\ ${ }^{a}$ Department of Clinical Immunology and Biochemical Genetics, Royal Perth Hospital, GPO Box X2213, Perth 6000, WA, Australia \\ ${ }^{\mathrm{b}}$ Department of Cardiology, Royal Perth Hospital, Perth, WA, Australia \\ ${ }^{\mathrm{c}}$ Department of Pathology, University of Western Australia, Perth, WA, Australia \\ ${ }^{\mathrm{d}}$ Department of Medicine, University of Western Australia, Perth, WA, Australia \\ ${ }^{\text {e }}$ Experimental Genetics Group, LEGT EGG, Department of Human Genetics, K. U. Leuven-Campus Gasthuisberg, O\&N 06B-3000 Leuven, Belgium
}

Received 28 October 2002; received in revised form 12 February 2003; accepted 24 February 2003

\begin{abstract}
The low density lipoprotein (LDL) receptor-related protein (LRP) is a multifunctional receptor involved in numerous biological processes relevant to vascular biology including lipoprotein metabolism. Several polymorphisms in the LRP gene have been described and in this study we examined their influence on coronary artery disease (CAD). We compared the frequencies of the exon 3 (C766T), exon 6 (C663T), exon 22 (C200T), and four rarer and more recently described polymorphisms in approximately 600 Caucasian subjects aged $<50$ years with angiographic CAD and approximately 700 similarly aged subjects without symptomatic CAD randomly selected from the community. We found the distribution of exon $22 \mathrm{C} 200 \mathrm{~T}$ genotypes to differ significantly between the CAD (CC: $52 \%$, CT: 39\%, TT: 9\%) and control subjects (CC: 43\%, CT: 46\%, TT: 11\%, $P=0.005$ ), with the CC genotype conferring an odds ratio (OR) for CAD of $1.5(95 \% \mathrm{CI}: 1.2-1.8, P=0.001)$ despite a lack of significant influence on plasma cholesterol or triglyceride. The other LRP polymorphisms were less common. Two showed an association with CAD; for the exon 3 C766T polymorphism the TT genotype was significantly lower $(1.0$ vs. $2.7 \%$; OR: $0.36 ; P=0.04)$ and, for the exon 6 C663T polymorphism, the heterozygote frequency was higher (6.2 vs. 3.4\%; OR: $1.9 ; P=0.03)$ in CAD subjects. In conclusion, LRP gene polymorphisms, particularly the relatively common exon $22 \mathrm{C} 200 \mathrm{~T}$ polymorphism, are a significant risk factor for premature CAD in Caucasians.
\end{abstract}

(C) 2003 Elsevier Science Ireland Ltd. All rights reserved.

Keywords: LDL receptor-related protein; Coronary artery disease; Genetic polymorphism

\section{Introduction}

Low density lipoprotein (LDL) receptor-related protein (LRP) is a multi-ligand receptor. It is also known as the $\alpha 2$-macroglobulin receptor, and its structure has a very high degree of homology to the LDL-receptor and other members of the LDL-receptor family [1]. It can bind and endocytose over 30 unrelated ligands many of which are of potential importance to the pathogenesis of

\footnotetext{
* Corresponding author. Tel.: +61-8-9224-2899; fax: +61-8-92242920.

E-mail address: cyril.mamotte@health.wa.gov.au (C. Mamotte).
}

obstructive coronary artery disease (CAD), including apolipoprotein E rich lipoproteins [2], chylomicron remnants [3-5], very low density lipoprotein [6], lipoprotein and hepatic lipase $[7,8]$ and other non-lipid related ligands such as plasminogen activator inhibitor I (PAI I) [9-11]. LRP has been found in smooth muscle cells and macrophages in both early and advanced atheromatous lesions in the human aorta, as well as in the normal aorta [12]. This is of interest because of the potential for LRP to promote unlimited cellular uptake of cholesterol-rich lipoprotein, a possibility related to the absence of any sterol regulatory element in its promoter region [13]. 
The human gene coding for LRP is located on chromosome $12 \mathrm{q} 13-\mathrm{q} 14$ [14]. It covers $\sim 90 \mathrm{~kb}$ of genomic DNA, contains 89 exons and codes for a 15 $\mathrm{kb}$ mRNA [15]. The gene is highly conserved with $97 \%$ amino acid homology between human and mouse LRP [16]. We have previously shown, by sequencing the 89 exons of human LRP, that the gene is polymorphic; most of the polymorphisms initially described, including the exon 3 C766T and exon 22 C200T polymorphisms, are not expressed [17]. The C766T polymorphism has been reported to be associated with Alzheimer's disease, albeit weakly [18-20]. LRP is a good candidate gene for $\mathrm{CAD}$, however, there have been very few attempts to determine the influence of the aforementioned polymorphisms, or that of the single previously well described and expressed polymorphism, exon 6 C663T $(\mathrm{A} 217 \mathrm{~V})$, on the risk of CAD. Four expressed polymorphisms, some of which involve non-conservative amino acid substitutions, were recently described: exon 14 G121C (A775P), exon 39 G52A (D2080N), exon 48 C92A (D2632E), and exon 85 G44A (G4379S); the influence of these on CAD is, likewise, also unknown.

To test the hypothesis that these LRP polymorphisms influence the risk of CAD, we carried out a case-control study focusing on relatively young subjects both because of the importance of premature CAD and because this strategy might be more likely to reveal a genetic influence. We examined LRP genotypes in a large number of patients aged $<50$ years, who have angiographic CAD with or without myocardial infarction (MI) and a similarly aged community group randomly selected from the electoral roll. Consecutive CAD subjects were all recruited prospectively at the one hospital for the purpose of risk factor and genetic studies.

\section{Methods}

\subsection{Study subjects}

The cases comprised approximately 600 Caucasian subjects aged less than 50 years $(44 \pm 0.2$, mean \pm S.E.M.), who presented to Royal Perth Hospital over a 6-year-period (1994-1999 inclusive) with clinical ischaemic heart disease, with $>50 \%$ diameter obstruction in at least one coronary artery assessed by coronary angiography, either with or without acute MI as assessed by historical, electrocardiographic and enzymatic parameters as previously described [21]. The characterisation as MI required all three of the following: typical chest pain $>20$ min duration, serum creatine kinase levels at least twice normal, ST segment elevation in at least two leads of a 12 lead electrocardiogram. All of those with MI also had confirmatory coronary angiography and left ventriculography. The exact numbers of DNA samples available for genotyping each polymorphism are noted subsequently.

The control subjects comprised approximately 700 Caucasians, aged $41 \pm 0.2$ years, selected randomly from the electoral roll, who took part in a National Heart Foundation community survey of CAD risk factors in the Perth metropolitan area in 1994 [21]. Each subject was documented with respect to lifestyle and medical demographics which included blood pressure, height and weight. Only those without a history suggestive of CAD were included in this study. There were no Australian Aboriginals in this community group and, although there were Aboriginals who presented with CAD, they and those of Asian descent were not included in this study because the frequency of polymorphisms in the gene for LRP might be racially dependent [22].

\subsection{Laboratory investigations}

Fasting blood samples were collected for measurement of plasma total cholesterol (TC), HDL-cholesterol (HDL-C), triglyceride (TG), and extraction of DNA. Samples from community subjects were taken at presentation to the survey centre and those from CAD subjects immediately preceding coronary angiography. Lipids were measured using enzymatic methods. The Friedewald formula was used to calculate LDL-cholesterol (LDL-C) in those with TG levels $<4.5 \mathrm{mmol} / 1$. DNA was extracted from $5 \mathrm{ml}$ of $\mathrm{K}_{2}$ EDTA anticoagulated blood using a Triton X-100 method [23]. The nature of the polymorphisms studied is listed in Table 1. Genotyping for LRP polymorphisms was carried out by restriction enzyme analysis of PCR amplified DNA spanning the polymorphic sites. Genotypes were determined by electrophoresis on $12 \%$ polyacrylamide gels $(25 \mathrm{~V} / \mathrm{cm}$ for $1.5 \mathrm{~h})$ and ethidium bromide staining after restriction enzyme digestion. The primer sequences, PCR amplicon size, PCR annealing temperatures, restriction enzymes and product sizes are shown in Table 2. Informed consent was obtained from all subjects and the study protocol was approved by the Royal Perth Hospital Ethics Committee.

\subsection{Statistical analyses}

To test for association between a polymorphism and $\mathrm{CAD}$, we compared the genotype and allele frequencies between CAD and control subjects using chi-square $\left(\chi^{2}\right)$ tests. Comparisons of plasma lipids including TC, LDLC, HDL-C and TG levels between subjects of different genotypes were carried out using analysis of variance (ANOVA). The lipid values were analysed separately in CAD and community groups, and separately for males and females. Variables are expressed as mean \pm S.E.M. except for TG results which are expressed as geometric means and $95 \%$ confidence intervals. Significance was 
Table 1

Genomic details of the LRP gene polymorphisms studied

\begin{tabular}{lllll}
\hline Polymorphism & Location $^{\mathrm{a}}$ & Polymorphic site & Amino acid change & Accession number \\
\hline Exon 3 C766T & Exon 3, 516 & atggacggct & None & AF058399 \\
Exon 6 C663T (A217V) & Exon 6, 663 & ggggccagg & Alanine to valine & AF058401 \\
Exon 14 G121C (A775P) & Exon 14, 343 & gaggcgcacc & Alanine to proline & AF058407 \\
Exon 22 C200T & Exon 22, 1209 & ctctgcggtg & None & AF058411 \\
Exon 39 G52A (D2080N) & Exon 39, 239 & ggatcgacct & Aspartic acid to asparagine & AF058416 \\
Exon 48 C92A (D2632E) & Exon 48, 1569 & gaggacgcct & Aspartic acid to glutamic acid & AF058419 \\
Exon 85 G44A (G4379S) & Exon 85, 2181 & gcgtcggcca & Glycine to serine & AF058427 \\
\hline
\end{tabular}

${ }^{a}$ Exon numbers and nucleotide positions in the indicated Gene Bank accession numbers are shown.

b Polymorphic sites are indicated in bold.

considered to be at $P<0.05$; however, $P$ values are also shown for statistical comparisons of borderline significance $(P: 0.05-0.1)$. Statistical analyses were performed using sPss for Windows version 9.0.1.

The characteristics of the two study groups in terms of conventional risk factors are summarised in Tables 3 and 4. The CAD subjects had a history of hypertension or diabetes more frequently, were more often smokers or ex-smokers and BMI was higher in both males and females compared with their respective control groups. The CAD patients were predominantly male $(88 \%)$ while approximately equal numbers of males $(51 \%)$ and females $(49 \%)$ were recruited in the community group. There were significant differences in lipids with CAD subjects of both sexes having a lower HDL-C and higher TG than their counterparts in the control group (Table 4); there was also a significant difference in TC between female, but not male, CAD and control subjects.

\section{Results and discussion}

The genotyping results are shown in Table 5. Genotype frequencies conformed to Hardy-Weinberg equilibrium in both the CAD and control groups, and in males and females separately. Most of our CAD subjects were male while there were similar number of males and females in the control group. However, there was no difference in the frequency of LRP genotypes between males and females in the control or CAD subjects and, on this basis, we consider pooling of genders for comparison of genotype frequencies to be valid. The four recently described expressed polymorphisms in exons 14, 39, 48 and 85 were extremely uncommon, consistent with the findings of the original report on several smaller cohorts [24], and with no homozygotes for the rarer alleles found (Table 5). Four heterozygotes for exon 14 G121C (A775P) were found in the CAD group and none in the control group $(P=0.03)$. How-

Table 2

Conditions for PCR and restriction enzyme analysis of LRP gene polymorphisms

\begin{tabular}{|c|c|c|c|c|c|}
\hline Polymorphism & Primers & Amplicon size (bp) & $\begin{array}{l}\text { PCR annealing } \\
\text { temperature }\left({ }^{\circ} \mathrm{C}\right)\end{array}$ & $\begin{array}{l}\text { Restriction } \\
\text { enzyme }\end{array}$ & $\begin{array}{l}\text { Restriction fragment } \\
\text { sizes }^{\mathrm{a}} \text { by allele (bp) }\end{array}$ \\
\hline Exon $3 \mathrm{C} 766 \mathrm{~T}$ & $\begin{array}{l}5^{\prime} \text {-ggggtccaggactgcatgta } \\
5^{\prime} \text {-aagtccgtacctcggcagtg }\end{array}$ & 59 & 54 & $R s a \mathrm{I}$ & $\begin{array}{l}\text { C: } 32,19,8 \\
\text { T: } 51,8\end{array}$ \\
\hline Exon 6 C663T (A217V) & $\begin{array}{l}5^{\prime} \text {-aacatcttggccacgtacct } \\
5^{\prime} \text {-cgtgctcgtaggtgtgatg }\end{array}$ & 60 & 58 & Hae III & $\begin{array}{l}\text { C: } 32,18,10 \\
\text { T: } 50,10\end{array}$ \\
\hline Exon 14 G121C (A775P) & $\begin{array}{l}5^{\prime} \text {-gcaactacctcttctggactg } \\
5^{\prime} \text {-cattgttcacccggcattt }\end{array}$ & 519 & 58 & Hae III & $\begin{array}{l}\text { G: } 372,104,43 \\
\text { C: } 372,67,43,37\end{array}$ \\
\hline Exon $22 \mathrm{C} 200 \mathrm{~T}$ & $\begin{array}{l}5 \text { '-gctcagatgagggcgagct } \\
5^{\prime} \text {-gtccttggcccagactccta }\end{array}$ & 86 & 59 & Mwo I & $\begin{array}{l}\text { C: } 67,19 \\
\text { T: } 86\end{array}$ \\
\hline Exon 39 G52A (D2080N) & $\begin{array}{l}5 \text {-aagctgtactggtgcgatg } \\
5^{\prime} \text {-tcacctgtcactccagtagat }\end{array}$ & 150 & 56 & $\operatorname{Taq} \mathrm{I}$ & $\begin{array}{l}\text { G: } 106,44 \\
\text { A: } 150\end{array}$ \\
\hline Exon 48 C92A (D2632E) & $\begin{array}{l}5 ' \text {-agcctgtggtgtgggcgagt } \\
5^{\prime} \text {-gctcgcagggctggaagagc }\end{array}$ & 518 & 64 & $B s a \mathrm{HI}$ & $\begin{array}{l}\text { C: } 400,87,31 \\
\text { A: } 400,118\end{array}$ \\
\hline Exon 85 G44A (G4379S) & $\begin{array}{l}5 \text {-gccccagctgtctgacct } \\
5^{\prime} \text {-tgctcaaatctggggaagg }\end{array}$ & 144 & 65 & Hae III & $\begin{array}{l}\text { G: } 67,51,26 \\
\text { A: } 93,51\end{array}$ \\
\hline
\end{tabular}

\footnotetext{
a Shown are restriction fragment sizes of the alleles for the various polymorphisms.
} 
Table 3

Characteristics of CAD and control subjects ${ }^{\mathrm{a}}$

\begin{tabular}{lll}
\hline & $\begin{array}{l}\text { CAD group } \\
(n=603)\end{array}$ & $\begin{array}{l}\text { Control group } \\
(n=694)\end{array}$ \\
\hline Age (years) & $44 \pm 0.2$ & $41 \pm 0.2$ \\
Males & $529(88 \%)$ & $352(51 \%)$ \\
MI previous & $173(29 \%)$ & \\
$\quad$ current & $200(33 \%)$ & \\
$\quad$ previous and current & $19(3 \%)$ & \\
Diabetes & $83(14 \%)$ & $8(1 \%)$ \\
Smoking current & $276(46 \%)$ & $168(24 \%)$ \\
$\quad$ ex & $208(34 \%)$ & $191(28 \%)$ \\
History of hypertension & $201(33 \%)$ & $113(16 \%)$ \\
BMI (kg/m $\left.{ }^{2}\right)$ & $28.4 \pm 0.2$ & $25.8 \pm 0.6$ \\
On lipid lowering drugs & $116(19 \%)$ & $10(1 \%)$ \\
\hline
\end{tabular}

CAD, coronary artery disease; $n$, number of subjects; BMI, body mass index.

a Continuous variables are expressed as mean \pm S.E.M. For dichotomous variables, percentages are given in parentheses. $\chi^{2}$ analysis was used to assess differences between variables. Each of the variables was significantly different between the two groups $(P<0.001)$.

ever, because of the rarity of this polymorphism and the number of comparisons we have carried out, we consider this result to be tentative rather than convincing evidence for a role in CAD. The other expressed polymorphism studied, the exon 6 C663T (A217V), has been described [17] but only previously examined in relation to Alzheimer's disease [25]. The $\mathrm{T}$ allele was associated with CAD, with CT heterozygosity conferring an OR of 1.9 for CAD (95\% CI: $1.1-3.3 ; P=0.03)$.

Of the two exonic non-expressed polymorphisms studied, the exon $22 \mathrm{C} 200 \mathrm{~T}$ polymorphism was common and significantly related to CAD, C homozygosity being associated with a higher risk when comparing the total CAD and control groups (OR: $1.5 ; 95 \% \mathrm{CI}: 1.2-1.8$; $P=0.001$ ), and in males (OR: $1.4 ; 95 \%$ CI: $1.0-1.8 ; P=$ 0.03 ) and females (OR: $1.9 ; 95 \% \mathrm{CI}: 1.1-3.2 ; P=0.02)$
Table 5

LRP genotype frequencies in CAD and control subjects

\begin{tabular}{|c|c|c|c|c|}
\hline \multirow{2}{*}{$\begin{array}{l}\text { LRP gene polymorphism } \\
\text { Expressed polymorphisms }\end{array}$} & \multirow[t]{2}{*}{ Genotype } & \multirow[t]{2}{*}{$\begin{array}{l}\text { CAD group } \\
n(\%)\end{array}$} & \multicolumn{2}{|c|}{$\begin{array}{l}\text { Control group } \\
n(\%)\end{array}$} \\
\hline & & & & \\
\hline \multirow{3}{*}{ Exon 6 C663T (A217V) } & $\mathrm{CC}$ & $556(94)$ & $597(96)$ & \\
\hline & $\mathrm{CT}$ & $37(6)$ & $21(3)^{\mathrm{b}}$ & $\mathrm{a}, \mathrm{c}$ \\
\hline & $\mathrm{TT}$ & $1(0.2)$ & $1(0.2)$ & \\
\hline \multirow[t]{3}{*}{ Exon 14 G121C (A775P) } & GG & $583(99)$ & $689(100)]$ & \\
\hline & $\mathrm{GC}$ & $4(0.7)$ & $-{ }^{\mathrm{e}}$ & d \\
\hline & $\mathrm{CC}$ & 0 & 0 & \\
\hline \multirow[t]{3}{*}{ Exon 39 G52A (D2080N) } & GG & $567(95)$ & $660(96)$ & \\
\hline & GA & $29(4.9)$ & $30(4.3)$ & \\
\hline & AA & 0 & 0 & \\
\hline \multirow[t]{3}{*}{ Exon 48 C92A (D2632E) } & $\mathrm{CC}$ & $587(99.8)$ & $691(99.9)$ & \\
\hline & $\mathrm{CA}$ & $1(0.2)$ & $1(0.1)$ & \\
\hline & AA & 0 & 0 & \\
\hline \multirow[t]{3}{*}{ Exon 85 G44A (G4379S) } & GG & $567(99.8)$ & $678(99.9)$ & \\
\hline & GA & $1(0.2)$ & $1(0.1)$ & \\
\hline & AA & 0 & 0 & \\
\hline \multicolumn{5}{|c|}{ Non-expressed polymorphisms } \\
\hline \multirow[t]{3}{*}{ Exon $3 \mathrm{C} 766 \mathrm{~T}$} & $\mathrm{CC}$ & $464(78)$ & $462(74)$ & \\
\hline & $\mathrm{CT}$ & $128(21)$ & $143(23)$ & f \\
\hline & TT & $6(1)$ & $\left.17(2.7)^{\mathrm{g}}\right]$ & \\
\hline \multirow[t]{3}{*}{ Exon $22 \mathrm{C} 200 \mathrm{~T}$} & $\mathrm{CC}$ & $308(52)$ & $\left.294(43)^{\mathrm{j}}\right]$ & \\
\hline & $\mathrm{CT}$ & $232(39)$ & $321(47)$ & h,i \\
\hline & TT & $55(9)$ & $75(11)$ & \\
\hline
\end{tabular}

Comparison of genotype distributions between CAD and control groups $\left(\chi^{2}\right)$ : ${ }^{\mathrm{a}} p=0.07 ;{ }^{\mathrm{d}} p=0.03 ;{ }^{\mathrm{f}} p=0.06 ;{ }^{\mathrm{h}} p=0.005$. Comparison of individual genotypes and/or alleles: ${ }^{\mathrm{b}} p=0.03(\mathrm{CT}) ;{ }^{\mathrm{c}} p=0.04$ (T and $\mathrm{C}$ alleles); ${ }^{\mathrm{e}} p=0.03$ (GC); ${ }^{\mathrm{g}} p=0.04$ (TT); ${ }^{\mathrm{i}} p=0.004$ ( $\mathrm{T}$ and $\mathrm{C}$ alleles); ${ }^{\mathrm{j}} p=0.001(\mathrm{CC})$.

separately. The $\mathrm{C}$ allele frequency was also significantly higher in the whole CAD group compared with the control group $(P=0.004)$, in males $(P=0.04)$ and females $(P=0.02)$ separately and, reciprocally, the $\mathrm{T}$ allele was significantly lower in the CAD group. This result is contrary to that reported, in smaller cohorts (153 CAD cases, 166 controls) in abstract form [26].

Table 4

Lipid values in CAD and control subjects ${ }^{\mathrm{d}}$

\begin{tabular}{llllll}
\hline & \multicolumn{2}{l}{ CAD group } & & \multicolumn{2}{c}{ Control group } \\
\cline { 2 - 3 } \cline { 5 - 6 } & Male $(n=529)$ & Female $(n=74)$ & Male $(n=352)$ & Female $(n=340)$ \\
\hline TC & $5.52 \pm 0.05$ & $5.28 \pm 0.14^{\mathrm{a}}$ & $5.42 \pm 0.06$ & $5.01 \pm 0.05^{\mathrm{a}}$ \\
HDL-C & $0.98 \pm 0.01^{\mathrm{b}}$ & $1.06 \pm 0.03^{\mathrm{b}}$ & $1.21 \pm 0.02^{\mathrm{b}}$ & $1.50 \pm 0.02^{\mathrm{b}}$ \\
LDL-C & $3.35 \pm 0.07^{\mathrm{c}}$ & $3.40 \pm 0.17$ & $3.53 \pm 0.05^{\mathrm{c}}$ & $3.07 \pm 0.04$ \\
TG & $1.92(1.83,2.02)^{\mathrm{b}}$ & $1.73(1.49,2.01)^{\mathrm{b}}$ & & $1.22(1.15,1.31)^{\mathrm{b}}$ & $0.83(0.79,0.88)^{\mathrm{b}}$ \\
\hline
\end{tabular}

TC, total cholesterol; HDL-C, HDL-cholesterol; LDL-C, LDL-cholesterol; TG, triglyceride. The $P$ values shown are for comparisons between $\mathrm{CAD}$ and control subjects of the same gender.

${ }^{\mathrm{a}} P=0.024$.

b $P<0.001$.

c $P=0.039$.

d The values $(\mathrm{mmol} / \mathrm{l})$ are expressed as mean \pm S.E.M., except for TG where geometric means and $95 \%$ confidence intervals are quoted. 
Table 6

Lipid values in CAD and control subjects for LRP Exon 22 C200T polymorphism ${ }^{\mathrm{a}}$

\begin{tabular}{|c|c|c|c|c|c|c|}
\hline & \multicolumn{3}{|l|}{ Male } & \multicolumn{3}{|l|}{ Female } \\
\hline & $\mathrm{CC}$ & CT & $\mathrm{TT}$ & $\mathrm{CC}$ & CT & $\mathrm{TT}$ \\
\hline CAD group & $(266)$ & $(205)$ & $(51)$ & $(42)$ & (27) & (4) \\
\hline $\mathrm{TC}$ & $5.44 \pm 0.07$ & $5.58 \pm 0.09$ & $5.81 \pm 0.23$ & $5.20 \pm 0.21$ & $5.39 \pm 0.20$ & $5.83 \pm 0.73$ \\
\hline HDL-C & $1.00 \pm 0.02$ & $0.99 \pm 0.02$ & $0.91 \pm 0.03$ & $1.05 \pm 0.05$ & $1.09 \pm 0.04$ & $1.00 \pm 0.16$ \\
\hline LDL-C & $3.38 \pm 0.10$ & $3.35 \pm 0.12$ & $3.17 \pm 0.22$ & $3.19 \pm 0.30$ & $3.50 \pm 0.20$ & 4.4 \\
\hline TG & $1.86(1.74,1.98)$ & $1.99(1.83,2.16)$ & $2.12(1.75,2.56)$ & $1.71(1.39,2.12)$ & $1.85(1.48,2.33)$ & $1.44(0.39,5.33)$ \\
\hline Control group & (153) & $(158)$ & (41) & (139) & $(163)$ & (34) \\
\hline $\mathrm{TC}$ & $5.46 \pm 0.08$ & $5.36 \pm 0.09$ & $5.53 \pm 0.20$ & $5.04 \pm 0.07$ & $5.01 \pm 0.07$ & $4.92 \pm 0.17$ \\
\hline HDL-C & $1.20 \pm 0.02$ & $1.23 \pm 0.03$ & $1.19 \pm 0.04$ & $1.48 \pm 0.03$ & $1.50 \pm 0.03$ & $1.59 \pm 0.05$ \\
\hline LDL-C & $3.59 \pm 0.07$ & $3.50 \pm 0.08$ & $3.50 \pm 0.18$ & $3.10 \pm 0.06$ & $3.07 \pm 0.06$ & $2.95 \pm 0.15$ \\
\hline TG & $1.22(1.10,1.34)$ & $1.17(1.06,1.30)$ & $1.41(1.14,1.73)$ & $0.86(0.79,0.94)$ & $0.82(0.75,0.89)$ & $0.75(0.64,0.89)$ \\
\hline
\end{tabular}

TC, total cholesterol; HDL-C, HDL-cholesterol; LDL-C, LDL-cholesterol; TG, triglyceride.

a The values $(\mathrm{mmol} / \mathrm{l})$ are expressed as mean \pm S.E.M., except for TG where geometric means and $95 \%$ confidence intervals are quoted. The number of subjects in each genotype category are shown in parentheses. Lipid values were not available for two female control subjects, both with the CC genotype.

The other exonic non-expressed polymorphism studied, the exon 3 C766T, has been considered, in several publications, to be associated with Alzheimer's disease although there has been recent doubt that any polymorphism in the LRP gene is so related [24]. There have been few studies in relation to CAD. In a Japanese association study on 445 cases and 464 controls, Yamada et al. [27] found no evidence of a role in MI $(P \geq 0.1)$. While there is concern regarding the appropriateness of the control group used in this Japanese study, as discussed by Peters and Boekholdt [28], the findings are consistent with those of Benes et al. [29]; in a Czech study of Caucasian CAD and control subjects older than ours, these investigators found no difference in C766T genotypes although there was a relationship of the $\mathrm{T}$ allele with CAD in those with a certain PAI 1 genotype, namely $5 \mathrm{G}$ homozygosity. By contrast, in our study, T homozygotes, which are relatively uncommon, were under-represented in those with CAD (OR: 0.36 for $\mathrm{CAD} ; 95 \% \mathrm{CI}: 0.1-0.9 ; P=0.04)$. The difference between the study of Yamada et al. [27] and ours may be due to ethnic differences or gene-environment interactions such as those involving lifestyle and diet. However, given that $\mathrm{T}$ homozygosity is not common, and in view of the number of statistical comparisons we have carried out, we do not consider our results on the exon $3 \mathrm{C} 766 \mathrm{~T}$ polymorphism to be a strong refutation of the negative findings of Yamada et al. [27] and Benes et al. [29]. If the exon $22 \mathrm{C} 200 \mathrm{~T}$ and exon $3 \mathrm{C} 766 \mathrm{~T}$ polymorphisms, neither of which are expressed polymorphisms, genuinely influence the risk of CAD, as clearly seems true for the $\mathrm{C} 200 \mathrm{~T}$, it must clearly be through linkage to some other polymorphism.

As already mentioned in Section 2, the CAD and control groups had significant differences in plasma lipids. However, there was no significant influence on TC, HDL-C, TG, or indeed LDL-C, in males or females, in either the CAD or control group for any of the polymorphisms studied. The results for the most relevant polymorphism to CAD, the exon $22 \mathrm{C} 200 \mathrm{~T}$, are shown in Table 6. A significant proportion (19\%) of the CAD subjects were on lipid lowering drugs. This and other aspects of their management may have confounded the results; however, this is not a consideration for the control group where only $1 \%$ were so affected. Of the few previous studies examining the influence of LRP polymorphisms on plasma lipids, none have shown a substantial effect; in a similarly sized study to ours, Benes et al. [29] found the C766T polymorphism to have no influence on plasma lipids and Harris et al. [22] and Hegele et al. [30] found a very weak association between the tetranucleotide repeat polymorphism in the LRP promoter, which was not studied here, and plasma lipids. In spite of our findings, we cannot completely exclude an influence on lipid metabolism; the subjects in our study were fasting and, given the role of LRP in chylomicron metabolism [31,32], studies on post-prandial chylomicron remnant clearance may be more relevant than the fasting lipids studied here. On the other hand, given the many potential roles of LRP in vascular biology, it is possible that the influence of LRP polymorphisms on CAD is not mediated through an influence on plasma lipids per se.

In summary, we have studied the influence of several LRP gene polymorphisms on the risk of premature CAD. A number, including the exon 14 G121C (A775P) and exon 6 C663T (A217V) polymorphisms, showed a marginally statistically significant association with CAD and their low frequency renders them relatively unimportant in the broader aetiological context. However, the C200T polymorphism in exon 22 is common and homozygosity for the $\mathrm{C}$ allele is significantly related to CAD. The mechanism responsible for this is unclear but 
demonstration of the association opens the way for further studies on the biological role of the LRP gene.

\section{Acknowledgements}

This study was supported by the Royal Perth Hospital Medical Research Foundation and the National Heart Foundation of Australia. We are grateful to Associate Professor Frank van Bockxmeer for serum and DNA samples on CAD and control subjects, and to Professor Konrad Jamrozik for recruitment of the community control subjects.

\section{References}

[1] Hussain MM, Strickland DK, Bakillah A. The mammalian lowdensity lipoprotein receptor family. Annu Rev Nutr 1999;19:14172 .

[2] Kowal RC, Herz J, Goldstein JL, Esser V, Brown MS. Low density lipoprotein receptor-related protein mediates uptake of cholesteryl esters derived from apoprotein E-enriched lipoproteins. Proc Natl Acad Sci USA 1989;86:5810-4.

[3] Mokuno H, Brady S, Kotite L, Herz J, Havel RJ. Effect of the 39$\mathrm{kDa}$ receptor-associated protein on the hepatic uptake and endocytosis of chylomicron remnants and low density lipoproteins in the rat. J Biol Chem 1994;269:13238-43.

[4] de Faria E, Fong LG, Komaromy M, Cooper AD. Relative roles of the LDL receptor, the LDL receptor-like protein, and hepatic lipase in chylomicron remnant removal by the liver. J Lipid Res 1996;37:197-209.

[5] Yu KC, Jiang Y, Chen W, Cooper AD. Evaluation of the components of the chylomicron remnant removal mechanism by use of the isolated perfused mouse liver. J Lipid Res 1999;40:1899-910.

[6] Chappell DA, Fry GL, Waknitz MA, et al. Lipoprotein lipase induces catabolism of normal triglyceride-rich lipoproteins via the low density lipoprotein receptor-related protein/alpha 2-macroglobulin receptor in vitro. A process facilitated by cell-surface proteoglycans. J Biol Chem 1993;268:14168-75.

[7] Chappell DA, Fry GL, Waknitz MA, Iverius PH, Williams SE, Strickland DK. The low density lipoprotein receptor-related protein/alpha 2-macroglobulin receptor binds and mediates catabolism of bovine milk lipoprotein lipase. J Biol Chem 1992;267:25764-7.

[8] Krapp A, Ahle S, Kersting S, et al. Hepatic lipase mediates the uptake of chylomicrons and beta-VLDL into cells via the LDL receptor-related protein (LRP). J Lipid Res 1996;37:926-36.

[9] Nykjaer A, Kjoller L, Cohen RL, et al. Regions involved in binding of urokinase-type-1 inhibitor complex and pro-urokinase to the endocytic alpha 2-macroglobulin receptor/low density lipoprotein receptor-related protein. Evidence that the urokinase receptor protects pro-urokinase against binding to the endocytic receptor. J Biol Chem 1994;269:25668-76.

[10] Vash B, Phung N, Zein S, DeCamp D. Three complement-type repeats of the low-density lipoprotein receptor-related protein define a common binding site for RAP, PAI-1, and lactoferrin. Blood 1998;92:3277-85.

[11] Horn IR, van den Berg BM, van der Meijden PZ, Pannekoek H, van Zonneveld AJ. Molecular analysis of ligand binding to the second cluster of complement-type repeats of the low density lipoprotein receptor-related protein. Evidence for an allosteric component in receptor-associated protein-mediated inhibition of ligand binding. J Biol Chem 1997;272:13608-13.

[12] Luoma J, Hiltunen T, Sarkioja T, et al. Expression of alpha 2macroglobulin receptor/low density lipoprotein receptor-related protein and scavenger receptor in human atherosclerotic lesions. $\mathbf{J}$ Clin Invest 1994;93:2014-21.

[13] Kutt H, Herz J, Stanley KK. Structure of the low-density lipoprotein receptor-related protein (LRP) promoter. Biochim Biophys Acta 1989;1009:229-36.

[14] Forus A, Myklebost O. A physical map of a $1.3-\mathrm{Mb}$ region on the long arm of chromosome 12, spanning the GLI and LRP loci. Genomics 1992;14:117-20.

[15] Van Leuven F, Stas L, Hilliker C, et al. Structure of the gene (LRP1) coding for the human alpha 2-macroglobulin receptor lipoprotein receptor-related protein. Genomics 1994;24:78-89.

[16] Van Leuven F, Stas L, Raymakers L, et al. Molecular cloning and sequencing of the murine alpha-2-macroglobulin receptor cDNA. Biochim Biophys Acta 1993;1173:71-4.

[17] Van Leuven F, Stas L, Thiry E, Nelissen B, Miyake Y. Strategy to sequence the 89 exons of the human LRP1 gene coding for the lipoprotein receptor related protein: identification of one expressed mutation among 48 polymorphisms. Genomics 1998;52:138-44.

[18] Baum L, Chen L, Ng HK, et al. Low density lipoprotein receptor related protein gene exon 3 polymorphism association with Alzheimer's disease in Chinese. Neurosci Lett 1998;247:33-6.

[19] Beffert U, Arguin C, Poirier J. The polymorphism in exon 3 of the low density lipoprotein receptor-related protein gene is weakly associated with Alzheimer's disease. Neurosci Lett 1999;259:2932.

[20] Hollenbach E, Ackermann S, Hyman BT, Rebeck GW. Confirmation of an association between a polymorphism in exon 3 of the low-density lipoprotein receptor-related protein gene and Alzheimer's disease. Neurology 1998;50:1905-7.

[21] van Bockxmeer FM, Liu Q, Mamotte C, Burke V, Taylor R. Lipoprotein lipase D9N, N291S and S447X polymorphisms: their influence on premature coronary heart disease and plasma lipids. Atherosclerosis 2001;157:123-9.

[22] Harris MR, Bunker CH, Hamman RF, Sanghera DK, Aston CE, Kamboh MI. Racial differences in the distribution of a low density lipoprotein receptor-related protein (LRP) polymorphism and its association with serum lipoprotein, lipid and apolipoprotein levels. Atherosclerosis 1998;137:187-95.

[23] Kunkel LM, Smith KD, Boyer SH, et al. Analysis of human Ychromosome-specific reiterated DNA in chromosome variants. Proc Natl Acad Sci USA 1977;74:1245-9.

[24] Van Leuven F, Thiry E, Lambrechts M, et al. Sequencing of the coding exons of the LRP1 and LDLR genes on individual DNA samples reveals novel mutations in both genes. Atherosclerosis 2001;154:567-77

[25] Wavrant-DeVrieze F, Lambert JC, Stas L, et al. Association between coding variability in the LRP gene and the risk of lateonset Alzheimer's disease. Hum Genet 1999;104:432-4.

[26] Schulz S, Handschug K, Schnurer C, et al. Polymorphism in the ligand binding domain of the LDL-receptor-related protein as an evident genetic risk marker for coronary atherosclerotic disease. Circulation 1998;98:532.

[27] Yamada Y, Izawa H, Ichihara S, et al. Prediction of the risk of myocardial infarction from polymorphisms in candidate genes. New Engl J Med 2002;347:1916-23.

[28] Peters RJG, Boekholdt SM. Gene polymorphisms and the risk of myocardial infarction - an emerging relation. New Engl J Med 2002;347:1963-5.

[29] Benes P, Muzik J, Benedik J, et al. The C766T low-density lipoprotein receptor related protein polymorphism and coronary artery disease, plasma lipoproteins, and longevity in the Czech population. J Mol Med 2001;79:116-20. 
[30] Hegele RA, Brunt JH, Connelly PW. Multiple genetic determinants of variation of plasma lipoproteins in Alberta Hutterites. Arterioscler Thromb Vasc Biol 1995;15:861-71.

[31] Veniant MM, Zlot CH, Walzem RL, et al. Lipoprotein clearance mechanisms in LDL receptor-deficient "Apo-B48-only" and “Apo-B100-only" mice. J Clin Invest 1998;102:1559-68.
[32] Herz J, Qiu SQ, Oesterle A, DeSilva HV, Shafi S, Havel RJ. Initial hepatic removal of chylomicron remnants is unaffected but endocytosis is delayed in mice lacking the low density lipoprotein receptor. Proc Natl Acad Sci USA 1995;92:4611-5. 